\title{
Reactive Astrocytes as Therapeutic Targets for Brain Degenerative Diseases: Roles Played by Metabotropic Glutamate Receptors
}

\author{
Talia M. Planas-Fontánez ${ }^{1,2}$ (i) $\cdot$ Cheryl F. Dreyfus ${ }^{2,3}$ (D) $\cdot$ Kyle S. Saitta $^{1,2}$ (i)
}

Received: 1 August 2019 / Revised: 13 January 2020 / Accepted: 18 January 2020 / Published online: 25 January 2020

(c) The Author(s) 2020

\begin{abstract}
Astrocytes are well known to play critical roles in the development and maintenance of the central nervous system (CNS). Moreover, recent reports indicate that these cells are heterogeneous with respect to the molecules they express and the functions they exhibit in the quiescent or activated state. Because astrocytes also contribute to pathology, promising new results raise the possibility of manipulating specific astroglial populations for therapeutic roles. In this mini-review, we highlight the function of metabotropic glutamate receptors (mGluRs), in particular mGluR3 and mGluR5, in reactive astrocytes and relate these to three degenerative CNS diseases: multiple sclerosis, Alzheimer's disease and Amyotrophic Lateral Sclerosis. Previous studies demonstrate that effects of these receptors may be beneficial, but this varies depending on the subtype of receptor, the state of the astrocytes, and the specific disease to which they are exposed. Elucidating the role of mGluRs on astrocytes at specific times during development and disease will provide novel insights in understanding how to best use these to serve as therapeutic targets.
\end{abstract}

Keywords Astrocyte heterogeneity · Group I/II metabotropic glutamate receptors · Multiple sclerosis · Alzheimer's disease $\cdot$ Amyotrophic lateral sclerosis

\section{Introduction}

It is well recognized that astrocytes play a number of critical roles that support the developing and mature brain. In response to injury, however, astrocytes exhibit profound changes in these roles that can result in both negative and positive influences on surrounding cells. We suggest that these roles can be harnessed to aid in the recovery from injury. In particular, we focus this mini-review on roles played by metabotropic glutamate receptors (mGluRs) that are expressed on astrocytes during disease. Recent studies suggest that stimulation of these receptors in some cases

Special Issue: In Honor of Professor Vittorio Gallo.

Cheryl F. Dreyfus

dreyfus@rwjms.rutgers.edu

1 Joint Graduate Program in Toxicology, Rutgers, The State University of New Jersey, Piscataway, NJ, USA

2 Department of Neuroscience and Cell Biology, Rutgers Robert Wood Johnson Medical School, Piscataway, NJ, USA

3 Robert Wood Johnson Medical School, 683 Hoes Lane West, Room 361, Piscataway, NJ 08854, USA may elicit protective effects on neighboring cells and may represent a new therapeutic approach to brain dysfunction. In other cases, however, antagonism may be preferable. Therefore, caution is warranted when evaluating effectiveness of mGluR stimulation (see Fig. 1). As indicated in this mini-review, astrocytes whether quiescent or reactive are highly heterogeneous populations with respect to their response to the local central nervous system (CNS) region in which they reside, and the specific diseases or injuries to which they are exposed. Therefore, the utility of application of specific agonists or antagonists may vary depending on the specific astrocytic populations under investigation and how they are impacted by their environment.

Before beginning it should be noted that we limit this review to astrocytes, their response to injury and effects of mGluR agonists. We recognize that other glial cells react to mGluR stimulation as well as other activating influences. For a more comprehensive analysis of responses of these cells we refer the reader to excellent additional reviews of this subject [1-5]. 


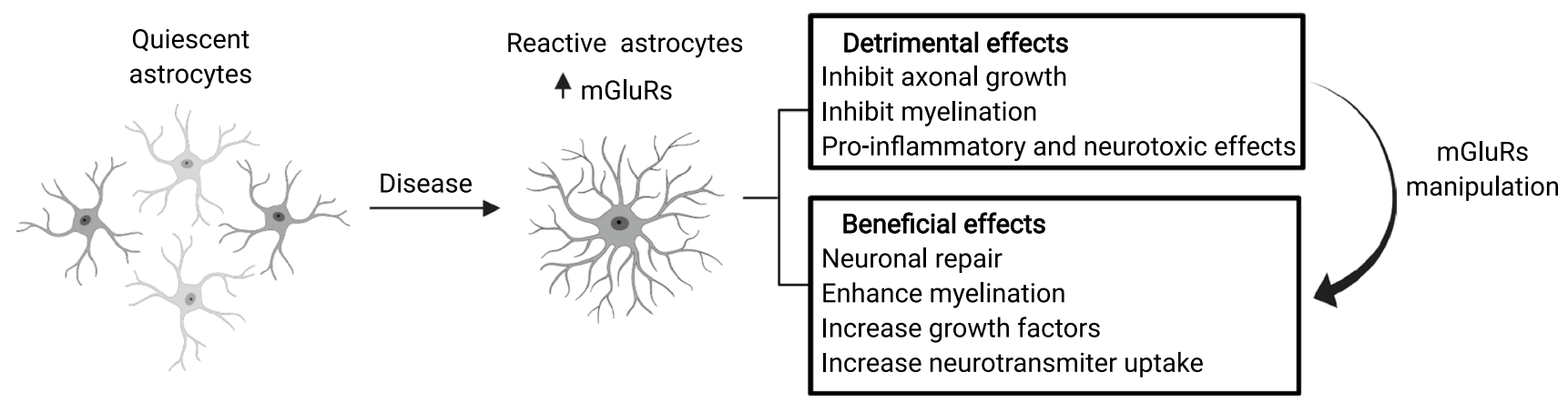

Fig. 1 Response of astrocytes to disease can be manipulated by mGluRs in a positive or negative direction depending on the state of astrocyte activation, the local astrocyte environment and the disease that is responsible for reactivity. Created with BioRender

\section{Astrocytic Function in the Unlesioned brain}

Astrocytes are the most abundant glial cell in the CNS and are specialized to perform many functions to support neuronal activity in the developing and adult nervous system. These include ion homeostasis, uptake of neurotransmitters, release of growth factors, participation in synaptic transmission, regulation of the blood-brain barrier and contribution to the CNS immune system [6]. Astrocytes also present a dynamic environment for axon guidance during development by providing appropriate cell surface receptors and adherent molecules [7].

Interestingly, many of the functions of astrocytes are regulated by neuron-to-astrocyte crosstalk. Astrocytes are able to respond to several neurotransmitters, including glutamate $[8,9]$, adenine triphosphate (ATP) $[10,11]$, gamma-aminobutyric acid (GABA) [12, 13], acetylcholine [14] and endocannabinoids [15]. In response to these transmitters, astrocytes elevate intracellular calcium levels, release a number of gliotransmitters as well as a host of growth factors that impact neuronal function [16, 17]. As a result of such signaling, astrocytes then modulate synaptic function, maintenance, pruning and remodeling and express ion channels and neurotransmitter receptors and transporters $[15,18,19]$. These physiological roles, manipulated by gliotransmitters and growth factors in normal astrocytes, are also observed during pathophysiological states of the nervous system, as discussed below.

Astrocytes are heterogeneous cells that not only differ in morphology and expression of intermediate filament levels, but also in the roles they play [20]. For example, morphological differences are reported when a subtype of astrocytes from the human cortex and hippocampus are compared. High levels of glutamine synthetase (GS) and excitatory amino-acid transporters -1 and -2 (EAAT1, EAAT2) are observed in the hippocampus with longprocess astrocytes, while cortical astrocytes are more heterogeneous with cells that are protoplasmic but exhibit reduced numbers of small processes and a low expression of GS, EAAT1, and EAAT2 [21]. As suggested here, the heterogeneity in morphology may extend to heterogeneity in function. This is indicated for example in the observation that astrocytes of different regions release different substances that may influence neighboring neurons distinctly. For example, cultured astrocytes of the substantia nigra are better at supporting dopamine neuron survival than are astrocytes of the hippocampus [22]. Such differences are also noted when substantia nigra astrocytes are compared to those of the ventral tegmental area. In this case, recent studies of effects of astrocytes on local dopaminergic neurons suggest that growth and differentiation factor 15 (GDF15), a member of the transforming growth factor beta (TGF- $\beta$ ) superfamily, may be responsible for differences in survival and protection when dopaminergic neurons from the two brain regions are compared [23].

Heterogeneity also is observed in the markers of astrocyte function within brain regions. For example, astrocytic $\alpha$-amino-3-hydroxy-5-methyl-4-isoxazolepropionic acid (AMPA) receptors, glutamate transporter 1 , and potassium channel Kir4.1 expression are differentially expressed within regions as well as between specific regions in the brain [24-27]. With respect to expression of mGluR5, examined in this mini-review, heterogeneity is also evident. Thus, few astrocytes of the spinal cord exhibit this receptor [28], while the majority of cortical astrocytes do [29]. It is important to consider what roles these differences may play when thinking of how regional astrocytes may differ in response to mGluR agonists in distinct disease states.

\section{Astrocytic Response to Injury}

In the case of brain injury or disease, astrocytes become reactive. In this process, many of the actions of quiescent cells become enhanced or reduced to influence proximate 
cells. Traditionally, it was thought that these changes are negative. For example, astrocytes can form a physical barrier to axon growth and produce a variety of molecules that serve as an impediment to nerve cell survival [30,31]. Moreover, reactive astrocytes express a wide variety of inflammationassociated molecules and are capable of antigen presentation. These changes have profound pro-inflammatory effects that present an inhibitory environment for glial differentiation and endogenous remyelination [32, 33]. In a more specific example, studies by the Gallo laboratory demonstrated that when effects of endothelin-1, a secreted intercellular signaling molecule were characterized after focal demyelination of the corpus callosum, it acted as a negative regulator of NG2 glial differentiation and functional remyelination [32]. Moreover, ablation or inhibition of endothelin receptor-B accelerates oligodendrocyte progenitor differentiation and remyelination [33]. Similarly, other proteins, such as bone morphogenetic proteins, have negative effects on oligodendrocytes following spinal cord injury (SCI) [34] and in the case of the mouse model of ALS, mutated astrocytes can release toxic factors that kill up to $90 \%$ of co-cultured motor neurons $[35,36]$. This has relevance to the response to disease states.

On the other hand, recently, it has become more widely recognized that astrocytes can also have neuroprotective effects and enhance axonal and neuronal regeneration [37, 38]. Reactive astrocytes in some cases suppress immune responses following CNS injury, maintain extracellular homeostasis and produce growth factors [39]. Thus, newly proliferated astrocytes may interact and organize into scars that surround and isolate tissue lesions and protect or enhance regeneration. For example, after SCI [40], signal transducer and activator of transcription 3 (STAT3), expressed by reactive astrocytes, has a key role in regeneration that includes control of inflammation [41, 42]. Selective deletion of the Stat 3 driver after a wound leads to a significant increase of immune cell infiltration and neurodegeneration $[38,43]$. These observations suggest that astrocytes may be critical for the recovery of function and survival after injury.

To evaluate the effects of injury on astrocyte function and their production of specific molecules, gene transcriptome approaches have been used to characterize subtypes of astroglial cells in response to brain damage. GeneChip analysis of reactive astrocytic populations was evaluated in two brain injury mice models: neuroinflammation induced by a single intraperitoneal injection of lipopolysaccharide and focal ischemic stroke produced by transient middle cerebral artery occlusion [44]. In both models, glial fibrillary acidic protein immunoreactivity is observed after 1 day and persists at least 1 week in combination with increased activated microglia. A core set of genes is upregulated in reactive astrocytes of both injury models, however, at least 50\% of the altered gene expression is specific to a given injury type. These data suggest that there are distinct subtypes of reactive astrocytes, reminiscent of distinct types of quiescent astrocytes. In the case of reactive astrocytes, these have been termed as A1 and A2 based on their detrimental or beneficial effects, respectively, during injury and repair [44-46].

A1 reactive astrocytes may have negative effects on surrounding cells in response to inflammation. For example, they may secrete molecules that are inhibitory to neurite outgrowth. In addition, swelling of these astrocytes after injury may result in the release of excessive amounts of glutamate. Liddelow et al. [46] suggests that this A1 activation may be induced by activated microglia through the secretion of cytokines. After induction, A1 astrocytes secrete a neurotoxin of uncertain identity that induces rapid death of neurons and oligodendrocytes. A2 astrocytes, in contrast, are commonly induced by ischemia and their responses to the ischemia are beneficial. This population is geared toward restoring trophic support and synapse repair and to promote the survival and growth of neurons [47]. A2 astrocytes express high levels of neurotrophic factors and cytokines, including brain-derived neurotrophic factor (BDNF), cardiotrophin-like cytokine factor 1 (CLCF1), interlukin-6 (IL-6), and GDF15, as well as thrombospondins that promote synapse repair $[44,48]$. Determining the cellular and molecular basis underlying A2 induction remains an issue to address and is important with respect to degenerative disease.

\section{Use of mGluRs to Regulate Astrocytes After Injury}

A number of studies have focused on astrocytic mGluRs as targets that can be manipulated to enhance repair after injury [5, 31, 45, 49, 50]. mGluRs, particularly mGluR3 and mGluR5, are the two most abundant mGluRs found on astrocytes [29, 51]. In response to injury, these receptors are upregulated at the lesion site, suggesting that astrocyte function can be influenced in the specific location where effects may be important. However, as noted previously, discretion is merited with respect to the function of these receptors. While some studies have described positive effects of astrocytic mGluR activation after injury through the actions of neurotrophins and growth factors [50, 52-55], others have reported that they may elicit harmful effects through the production of cytokines and inflammatory mediators [56]. These differences in effect may be due to the state of activation of astrocytes, the region being assessed and the type of lesion being examined [29, 45, 46, 57, 58]. Consequently, environmental distinctions must be taken into consideration when assessing astrocytic mGluRs as potential pharmacological targets and included in determining whether stimulation of these receptors should be enhanced or inhibited. 


\section{Signaling by and Regional Expression of Astrocytic mGluR3 and mGluR5}

mGluRs are $\mathrm{G}$ protein-coupled receptors consisting of seven transmembrane domains that are subdivided into Group I, II, and III based on their signaling transduction pathways, amino acid sequence homology, and selectivity of agonists and antagonists $[1,2,5,59,60]$. mGluR5, in addition to mGluR1, is classified as a Group I mGluR, while mGluR3 is part of the Group II mGluRs along with mGluR2. Group I mGluRs function through $\mathrm{G}_{\mathrm{q}}$-proteins, resulting in activation of phospholipase C (PLC), hydrolysis of phosphoinositides, release of calcium, and activation of protein kinase $\mathrm{C}$ (PKC). Further downstream signaling pathways include casein kinase 1, cyclin-dependent protein kinase 5, Jun kinase, mitogen-activated protein kinase/extracellular receptor kinase, and mammalian target of rapamycin/p70 S6 kinase [61-66]. On the other hand, Group II mGluRs are associated with $\mathrm{G}_{\mathrm{i}}$ - and $\mathrm{G}_{0}$-proteins, and are negatively coupled to adenylate cyclase. Activation of Group II mGluRs inhibits voltage-gated calcium entry into the cell. In addition, these receptors can activate MAPK and phosphatidyl inositol 3-kinase pathways [1, 2, $5,59,67,68]$.

Gene expression analysis has been done to study the presence of mGluR3 and mGluR5 specifically on astrocytes isolated from mouse hippocampus or cortex. These studies reveal that while all mGluRs are found at least at low levels in adult tissue in mice, the most abundant receptor is mGluR3 followed by mGluR5 [51]. These two mGluRs are also present in humans under normal conditions, while others are undetectable [51, 69-71]. It is of interest that in some cases expression of the receptors changes with development, but not in others, suggesting that the role of specific receptors may be altered as the brain matures. Astrocytic mGluR3 expression remains relatively stable at 1-, 2-, 3-, and 12-weeks of age [51], while mGluR5 expression is highest at postnatal day 7 [51, 72] before rapidly declining through adulthood [51, 72].

To examine the presence of these receptors in astrocytes in vitro, cells are removed from developing animals and grown in culture. This approach has the advantage of evaluating the isolated cells, examining their receptors and defining their function. In general, as was the case in vivo, mGluR3 and mGluR5 show strong expression when compared to all the other mGluRs [29]. Interestingly, culture studies also reveal that regional differences are apparent. While mGluR3 and mGluR5 are found in astrocytes isolated from thalamus, tegmentum, cortex, hippocampus, and striatum [29], there are almost undetectable levels of these receptors within the cerebellum [29] and spinal cord
[28]. It is interesting to consider what these regional differences may signify. Transcriptome analysis has indicated that cultured astrocytes exhibit a phenotype akin to A2 reactive astrocytes of the ischemic brain [44]. These studies suggest that regional differences in astrocyte expression of mGluRs in culture may foretell regional differences that while not evident in vivo, will be evident after specific injuries.

Rodent brain slices have been studied to bridge the gap between in vitro and in vivo studies. In particular, specific agonists of Group I and/or Group II mGluRs induce transient increases in intracellular calcium levels within astrocytes of hippocampal slices as they do in vivo [73-77]. In concordance with in vivo studies also is the fact that astrocytic mGluR5 is developmentally regulated in slices with the highest expression occurring in slices isolated from P1-10 rodents before declining into adulthood [78, 79].

In models of disease and in human disease tissue, levels of astrocytic mGluRs are upregulated in or near lesions. Therefore, we propose that the roles of these receptors may be most apparent during development, become downregulated during adulthood, but emerge to play critical roles during CNS disease. The models in which mGluR5 is elevated include multiple sclerosis (MS) [50], Alzheimer's disease (AD) [80], amyotrophic lateral sclerosis (ALS) [81], epilepsy [82-85] and SCI [86-88]. Similarly, astrocytic mGluR5 is upregulated in human tissue from patients with MS [69, 71], AD [89, 90], ALS [91, 92] and epilepsy [93-95]. In regards to mGluR3, its expression is enhanced on astrocytes in animal models of epilepsy $[82,83]$ and in human tissue taken from patients with MS [69, 71], ALS [91, 92] and epilepsy [94].

\section{Roles of mGluRs on Reactive Astrocytes}

In general, stimulation of Group I and/or Group II mGluRs on reactive astrocytes leads to the release of neurotransmitters, including glutamate [29, 73, 96, 97], as well as other factors such as BDNF [55, 98], glial-derived neurotrophic factor (GDNF) [54], and TGF- $\beta$ [52, 53]. Astrocytic mGluR activation can also lead to enhanced glutamate uptake through Group I or II receptors [99, 100]. These data suggest that astrocytic mGluRs have the potential to play positive roles in the diseased brain. Nevertheless, these effects may vary based on the different environments of the different diseases. For example, as will be discussed in the next section, mGluR stimulation may elicit positive astrocytic effects in diseases such as $\mathrm{MS}$ and $\mathrm{AD}$, while eliciting mixed effects in other diseases like ALS. 


\section{Roles of mGluR3 and mGluR5 in Response to Disease}

\section{Multiple Sclerosis}

mGluR5 is increased in reactive astrocytes specifically within the lesion sites of the cuprizone model of MS [50]. This increase is not found on microglia or $\mathrm{CC} 1+$ mature oligodendrocytes. In the experimental autoimmune encephalomyelitis (EAE) model of MS, studies of tissue samples taken from EAE rodents indicate an increase in mGluR5 in the whole brain and forebrain. However, the cells expressing these receptors were not identified [101, 102]. In an attempt to determine roles of mGluR agonists and antagonists in rodent models of MS, these drugs have been injected either locally within the lesion site or systemically. The Group I/ Group II mGluR agonist trans-(1S,3R)-1-amino-1,3-cyclopentanedicarboxylic acid (ACPD) injected directly into the cuprizone-induced lesion increases synthesis and release of BDNF, an effect that is blocked when BDNF was selectively deleted from astrocytes, suggesting that the mGluRs mediate the increase in this trophic factor in astrocytes [50].

In the case of the EAE models, effects of the mGluR agonists and antagonists were injected into the whole animal making the relative contribution of these receptors on astrocytes compared to other cell types unknown. In this model, mGluR5 antagonists have no effect on motor function [103], nor do they affect myelin ultrastructure compared to EAE animals receiving vehicle [102, 104, 105], suggesting that actions of mGluRs in EAE may be different from those in the cuprizone model. It should be noted however, that application of the agonists to the EAE CNS as a whole may miss a subtle difference elicited through the actions of astrocytes that can be enhanced. Clearly, additional studies are needed to identify which cells express mGluRs. This makes it possible to elucidate roles of agonists and determine their potential to signal though mGluRs on astrocytes or other cell types.

\section{Alzheimer's Disease}

In vivo studies of mGluRs and astrocytes in $A D$ are quite limited, however it is interesting to note that amyloid-beta $(\mathrm{A} \beta)$ increases expression of mGluR5 in an AD transgenic model [80]. This effect also occurs when $A \beta$ is added to astrocytes in culture $[80,89,90,106]$, indicating that when this agent is elevated, roles of astrocytic mGluR5 may be enhanced. However, information is lacking as to what the consequence is of this upregulation.

Culture models of AD are most informative in defining effects of mGluRs on astrocytes. These indicate that
mGluRs are present on astrocytes in these models. In general, stimulation of the receptors has had beneficial results. This is most well known with respect to Group II receptors. For example, astrocytic Group II activation reduces $A \beta$ production [107], and increases $A \beta$ uptake in astrocytes, as well as releases BDNF from these cells [55]. BDNF in this study enhances neuron survival when neurons are challenged by treatment with $A \beta$. In complementary work, stimulation with ACPD that stimulates both Group I and Group II receptors also increases BDNF synthesis and release [98]. Other studies indicate that stimulation of mGluR3 reduces A $\beta$-induced neurodegeneration in mixed neuronal-glia cultures [53]. This effect is blocked when the receptor function is inhibited or when astrocytes are derived from mGluR3 deleted mice. In this case, mGluR 3 rescues the neurons from $A \beta$-elicited death through the action of astrocyte-derived TGF- $\beta$. Overall, these studies in culture models of AD indicate that both astrocyte-derived BDNF and TGF- $\beta$ may play positive protective roles in this disease and that this may be regulated by mGluRs.

\section{Amyotrophic Lateral Sclerosis}

In ALS, studies of the role of astrocytic mGluR5 have focused on astrocytes cultured from animal models of the disease, particularly the hSOD1 ${ }^{\mathrm{G} 93 \mathrm{~A}}$ mouse or rat models. These studies find that mGluR5 is expressed at three-fold greater levels in hSOD1 ${ }^{\mathrm{G} 93 \mathrm{~A}}$ astrocytes than in wild-type cells [81]. In this disease however, upregulation of astrocytic mGluR5 appears to have negative consequences. Stimulation of Group I mGluRs on hSOD $1^{\mathrm{G} 93 \mathrm{~A}}$ astrocytes results in the death of these cells and this effect is blocked with an mGluR5 antagonist [108]. Moreover, while wild-type astrocytes treated with a Group I agonist enhances aspartate uptake, astrocytes derived from $\mathrm{hSOD} 1^{\mathrm{G} 93 \mathrm{~A}}$ rats fail to increase aspartate uptake, indicating that the mutant gene blocks protective roles of the Group I agonist [81, 109]. Proper removal of excitatory transmitters such as aspartate and glutamate can be important in preventing excitotoxicity in diseases such as ALS, where increased glutamate levels and reduced glutamate transporter expression is evident in tissue from ALS patients [110, 111]. Inhibiting mGluR5 activity on hSOD $1^{\mathrm{G} 93 \mathrm{~A}}$ astrocytes is then a strategy that may be pursued to enhance protective astrocytic functions.

In contrast to activation of Group I receptors, potential actions of Group II mGluRs on hSOD $1^{\mathrm{G} 93 \mathrm{~A}}$ astrocytes have not yet been studied in culture. However, effects of a Group II agonist injected subcutaneously have been studied in hSOD $1^{\mathrm{G} 93 \mathrm{~A}}$ mice [54]. Injection results in reduced neuronal death and elevated GDNF levels in the spinal cord with corresponding improvements in motor performance and neurologic signs. The same study shows that the Group 
II agonist enhances GDNF release from cultured wild-type astrocytes through mGluR3. It is not yet known if astrocytes are responsible for the effects observed in $\mathrm{hSOD} 1{ }^{\mathrm{G} 93 \mathrm{~A}}$ mice.

\section{Conclusions}

This mini-review has documented a number of studies that suggest the possible importance of astrocytes as therapeutic targets in treatment of CNS disease. In particular, we summarize roles of quiescent astrocytes and how they alter their functions in response to injury. In discussing these events it becomes obvious that astrocytes are not simple homogeneous populations. Their critical impact on the maintenance of CNS function has been increasingly recognized. However, what is still generally unappreciated is their heterogeneity in function and in response to disease. We focus this review on the roles played by mGluR3 and mGluR5, recognizing that these receptors are only representative of multiple receptors that influence function. What has been obvious, however, is that these receptors are upregulated on astrocytes at or near lesion sites, putting them in optimal position to have important influences under these conditions. Moreover, manipulation of signaling through these receptors is beginning to emerge as a strategy worth pursuing in at least some disease conditions.

One note about the studies that have been discussed: Although descriptive work assesses how astrocytes respond to injury and where mGluRs are expressed on astrocytes, it has been difficult to attribute the results of manipulation of these cells and these receptors to function in vivo. Critical work is clearly necessary to extend studies of function by using new animal models where astrocytes specifically can be manipulated by the deletion of a particular protein at distinct time points as is now being done in a number of studies $[50,100]$.

Acknowledgements The work by the Dreyfus laboratory cited in this review was supported by NMSS Grant RG 4257B4/1 and National Institute of Neurological Disorders and Stroke NIH R01 NS036647.

Open Access This article is licensed under a Creative Commons Attribution 4.0 International License, which permits use, sharing, adaptation, distribution and reproduction in any medium or format, as long as you give appropriate credit to the original author(s) and the source, provide a link to the Creative Commons licence, and indicate if changes were made. The images or other third party material in this article are included in the article's Creative Commons licence, unless indicated otherwise in a credit line to the material. If material is not included in the article's Creative Commons licence and your intended use is not permitted by statutory regulation or exceeds the permitted use, you will need to obtain permission directly from the copyright holder. To view a copy of this licence, visit http://creativecommons.org/licenses/by/4.0/.

\section{References}

1. D’Antoni S, Berretta A, Bonaccorso CM, Bruno V, Aronica E, Nicoletti F, Catania MV (2008) Metabotropic glutamate receptors in glial cells. Neurochem Res 33(12):2436-2443. https://doi. org/10.1007/s11064-008-9694-9

2. Byrnes KR, Loane DJ, Faden AI (2009) Metabotropic glutamate receptors as targets for multipotential treatment of neurological disorders. Neurotherapeutics 6(1):94-107. https://doi. org/10.1016/j.nurt.2008.10.038

3. Bradley SJ, Challiss RA (2012) G protein-coupled receptor signalling in astrocytes in health and disease: a focus on metabotropic glutamate receptors. Biochem Pharmacol 84(3):249-259. https://doi.org/10.1016/j.bcp.2012.04.009

4. Loane DJ, Stoica BA, Faden AI (2012) Metabotropic glutamate receptor-mediated signaling in neuroglia. Wiley Interdiscip Rev Membr Transp Signal 1(2):136-150. https://doi. org/10.1002/wmts.30

5. Spampinato SF, Copani A, Nicoletti F, Sortino MA, Caraci F (2018) Metabotropic glutamate receptors in glial cells: a new potential target for neuroprotection? Front Mol Neurosci 11:414. https://doi.org/10.3389/fnmol.2018.00414

6. Sofroniew MV, Vinters HV (2010) Astrocytes: biology and pathology. Acta Neuropathol 119(1):7-35. https://doi. org/10.1007/s00401-009-0619-8

7. Powell EM, Meiners S, DiProspero NA, Geller HM (1997) Mechanisms of astrocyte-directed neurite guidance. Cell Tissue Res 290(2):385-393. https://doi.org/10.1007/s004410050 945

8. Di Castro MA, Chuquet J, Liaudet N, Bhaukaurally K, Santello M, Bouvier D, Tiret P, Volterra A (2011) Local Ca2+ detection and modulation of synaptic release by astrocytes. Nat Neurosci 14(10):1276-1284. https://doi.org/10.1038/nn.2929

9. Perea G, Araque A (2005) Glial calcium signaling and neuronglia communication. Cell Calcium 38(3-4):375-382. https://doi. org/10.1016/j.ceca.2005.06.015

10. Bowser DN, Khakh BS (2004) ATP excites interneurons and astrocytes to increase synaptic inhibition in neuronal networks. J Neurosci 24(39):8606-8620. https://doi.org/10.1523/jneur osci.2660-04.2004

11. Perea G, Araque A (2007) Astrocytes potentiate transmitter release at single hippocampal synapses. Science 317(5841):1083-1086. https://doi.org/10.1126/science.1144640

12. Perea G, Gomez R, Mederos S, Covelo A, Ballesteros JJ, Schlosser L, Hernandez-Vivanco A, Martin-Fernandez M, Quintana R, Rayan A, Diez A, Fuenzalida M, Agarwal A, Bergles DE, Bettler B, Manahan-Vaughan D, Martin ED, Kirchhoff F, Araque A (2016) Activity-dependent switch of GABAergic inhibition into glutamatergic excitation in astrocyte-neuron networks. eLife. https://doi.org/10.7554/eLife.20362

13. Mariotti L, Losi G, Lia A, Melone M, Chiavegato A, GomezGonzalo M, Sessolo M, Bovetti S, Forli A, Zonta M, Requie LM, Marcon I, Pugliese A, Viollet C, Bettler B, Fellin T, Conti F, Carmignoto G (2018) Interneuron-specific signaling evokes distinctive somatostatin-mediated responses in adult cortical astrocytes. Nat Commun 9(1):82. https://doi.org/10.1038/s4146 7-017-02642-6

14. Chen N, Sugihara H, Sharma J, Perea G, Petravicz J, Le C, Sur M (2012) Nucleus basalis-enabled stimulus-specific plasticity in the visual cortex is mediated by astrocytes. Proc Natl Acad Sci USA 109(41):E2832-E2841. https://doi.org/10.1073/pnas.12065 57109

15. Navarrete M, Araque A (2008) Endocannabinoids mediate neuron-astrocyte communication. Neuron 57(6):883-893. https:// doi.org/10.1016/j.neuron.2008.01.029 
16. Martin DL (1992) Synthesis and release of neuroactive substances by glial cells. Glia 5(2):81-94. https://doi.org/10.1002/ glia.440050202

17. Nedergaard M, Ransom B, Goldman SA (2003) New roles for astrocytes: redefining the functional architecture of the brain. Trends Neurosci 26(10):523-530. https://doi.org/10.1016/j. tins.2003.08.008

18. Kang J, Jiang L, Goldman SA, Nedergaard M (1998) Astrocytemediated potentiation of inhibitory synaptic transmission. Nat Neurosci 1(8):683-692. https://doi.org/10.1038/3684

19. Guthrie PB, Knappenberger J, Segal M, Bennett MV, Charles AC, Kater SB (1999) ATP released from astrocytes mediates glial calcium waves. J Neurosci 19(2):520-528

20. Wilkin GP, Marriott DR, Cholewinski AJ (1990) Astrocyte heterogeneity. Trends Neurosci 13(2):43-46

21. Sosunov AA, Wu X, Tsankova NM, Guilfoyle E, McKhann GM, Goldman JE (2014) Phenotypic heterogeneity and plasticity of isocortical and hippocampal astrocytes in the human brain. J Neurosci 34(6):2285-2298. https://doi.org/10.1523/jneur osci.4037-13.2014

22. O'Malley EK, Sieber BA, Black IB, Dreyfus CF (1992) Mesencephalic type I astrocytes mediate the survival of substantia nigra dopaminergic neurons in culture. Brain Res 582(1):65-70. https ://doi.org/10.1016/0006-8993(92)90317-3

23. Kostuk EW, Cai J, Iacovitti L (2019) Subregional differences in astrocytes underlie selective neurodegeneration or protection in Parkinson's disease models in culture. Glia 67(8):1542-1557. https://doi.org/10.1002/glia.23627

24. Hoft S, Griemsmann S, Seifert G, Steinhauser C (2014) Heterogeneity in expression of functional ionotropic glutamate and GABA receptors in astrocytes across brain regions: insights from the thalamus. Philos Trans R Soc London B 369(1654):20130602. https://doi.org/10.1098/rstb.2013.0602

25. Emsley JG, Macklis JD (2006) Astroglial heterogeneity closely reflects the neuronal-defined anatomy of the adult murine CNS. Neuron Glia Biol 2(3):175-186. https://doi.org/10.1017/s1740 $925 \times 06000202$

26. Regan MR, Huang YH, Kim YS, Dykes-Hoberg MI, Jin L, Watkins AM, Bergles DE, Rothstein JD (2007) Variations in promoter activity reveal a differential expression and physiology of glutamate transporters by glia in the developing and mature CNS. J Neurosci 27(25):6607-6619. https://doi.org/10.1523/ jneurosci.0790-07.2007

27. Poopalasundaram S, Knott C, Shamotienko OG, Foran PG, Dolly JO, Ghiani CA, Gallo V, Wilkin GP (2000) Glial heterogeneity in expression of the inwardly rectifying $\mathrm{K}(+)$ channel, Kir4.1, in adult rat CNS. Glia 30(4):362-372

28. Silva GA, Theriault E, Mills LR, Pennefather PS, Feeney CJ (1999) Group I and II metabotropic glutamate receptor expression in cultured rat spinal cord astrocytes. Neurosci Lett 263(2-3):117-120

29. Biber K, Laurie DJ, Berthele A, Sommer B, Tolle TR, GebickeHarter PJ, van Calker D, Boddeke HW (1999) Expression and signaling of group I metabotropic glutamate receptors in astrocytes and microglia. J Neurochem 72(4):1671-1680

30. Ohtake Y, Li S (2015) Molecular mechanisms of scar-sourced axon growth inhibitors. Brain Res 1619:22-35. https://doi. org/10.1016/j.brainres.2014.08.064

31. Adams KL, Gallo V (2018) The diversity and disparity of the glial scar. Nat Neurosci 21(1):9-15. https://doi.org/10.1038/ s41593-017-0033-9

32. Hammond TR, Gadea A, Dupree J, Kerninon C, Nait-Oumesmar B, Aguirre A, Gallo V (2014) Astrocyte-derived endothelin-1 inhibits remyelination through notch activation. Neuron 81(3):588-602. https://doi.org/10.1016/j.neuron.2013.11.015
33. Hammond TR, McEllin B, Morton PD, Raymond M, Dupree J, Gallo V (2015) Endothelin-B receptor activation in astrocytes regulates the rate of oligodendrocyte regeneration during remyelination. Cell Rep 13(10):2090-2097. https://doi.org/10.1016/j. celrep.2015.11.002

34. Wang Y, Cheng X, He Q, Zheng Y, Kim DH, Whittemore SR, Cao QL (2011) Astrocytes from the contused spinal cord inhibit oligodendrocyte differentiation of adult oligodendrocyte precursor cells by increasing the expression of bone morphogenetic proteins. J Neurosci 31(16):6053-6058. https://doi.org/10.1523/ jneurosci.5524-09.2011

35. Diaz-Amarilla P, Olivera-Bravo S, Trias E, Cragnolini A, Martinez-Palma L, Cassina P, Beckman J, Barbeito L (2011) Phenotypically aberrant astrocytes that promote motoneuron damage in a model of inherited amyotrophic lateral sclerosis. Proc Natl Acad Sci USA 108(44):18126-18131. https://doi.org/10.1073/ pnas. 1110689108

36. Trias E, Diaz-Amarilla P, Olivera-Bravo S, Isasi E, Drechsel DA, Lopez N, Bradford CS, Ireton KE, Beckman JS, Barbeito L (2013) Phenotypic transition of microglia into astrocyte-like cells associated with disease onset in a model of inherited ALS. Front Cell Neurosci 7:274. https://doi.org/10.3389/fncel.2013.00274

37. Faulkner JR, Herrmann JE, Woo MJ, Tansey KE, Doan NB, Sofroniew MV (2004) Reactive astrocytes protect tissue and preserve function after spinal cord injury. J Neurosci 24(9):21432155. https://doi.org/10.1523/jneurosci.3547-03.2004

38. Anderson MA, Burda JE, Ren Y, Ao Y, O'Shea TM, Kawaguchi R, Coppola G, Khakh BS, Deming TJ, Sofroniew MV (2016) Astrocyte scar formation aids central nervous system axon regeneration. Nature 532(7598):195-200. https://doi.org/10.1038/ nature 17623

39. Belanger M, Magistretti PJ (2009) The role of astroglia in neuroprotection. Dialog Clin Neurosci 11(3):281-295

40. Wanner IB, Anderson MA, Song B, Levine J, Fernandez A, GrayThompson Z, Ao Y, Sofroniew MV (2013) Glial scar borders are formed by newly proliferated, elongated astrocytes that interact to corral inflammatory and fibrotic cells via STAT3-dependent mechanisms after spinal cord injury. J Neurosci 33(31):1287012886. https://doi.org/10.1523/jneurosci.2121-13.2013

41. Zhong Z, Wen Z, Darnell JE Jr (1994) Stat3: a STAT family member activated by tyrosine phosphorylation in response to epidermal growth factor and interleukin-6. Science 264(5155):9598. https://doi.org/10.1126/science. 8140422

42. Hong S, Song MR (2014) STAT3 but not STAT1 is required for astrocyte differentiation. PLoS ONE 9(1):e86851. https://doi. org/10.1371/journal.pone.0086851

43. Bush TG, Puvanachandra N, Horner CH, Polito A, Ostenfeld T, Svendsen CN, Mucke L, Johnson MH, Sofroniew MV (1999) Leukocyte infiltration, neuronal degeneration, and neurite outgrowth after ablation of scar-forming, reactive astrocytes in adult transgenic mice. Neuron 23(2):297-308

44. Zamanian JL, Xu L, Foo LC, Nouri N, Zhou L, Giffard RG, Barres BA (2012) Genomic analysis of reactive astrogliosis. J Neurosci 32(18):6391-6410. https://doi.org/10.1523/jneur osci.6221-11.2012

45. Liddelow SA, Barres BA (2017) Reactive astrocytes: production, function, and therapeutic potential. Immunity 46(6):957-967. https://doi.org/10.1016/j.immuni.2017.06.006

46. Liddelow SA, Guttenplan KA, Clarke LE, Bennett FC, Bohlen CJ, Schirmer L, Bennett ML, Munch AE, Chung WS, Peterson TC, Wilton DK, Frouin A, Napier BA, Panicker N, Kumar M, Buckwalter MS, Rowitch DH, Dawson VL, Dawson TM, Stevens B, Barres BA (2017) Neurotoxic reactive astrocytes are induced by activated microglia. Nature 541(7638):481-487. https://doi. org/10.1038/nature21029 
47. Hayakawa K, Pham LD, Arai K, Lo EH (2014) Reactive astrocytes promote adhesive interactions between brain endothelium and endothelial progenitor cells via HMGB1 and beta-2 integrin signaling. Stem Cell Res 12(2):531-538. https://doi. org/10.1016/j.scr.2013.12.008

48. Eroglu C (2009) The role of astrocyte-secreted matricellular proteins in central nervous system development and function. Journal of cell communication signaling 3(3-4):167-176. https ://doi.org/10.1007/s12079-009-0078-y

49. Miller SJ (2018) Astrocyte heterogeneity in the adult central nervous system. Front Cell Neurosci 12:401. https://doi. org/10.3389/fncel.2018.00401

50. Fulmer CG, VonDran MW, Stillman AA, Huang Y, Hempstead BL, Dreyfus CF (2014) Astrocyte-derived BDNF supports myelin protein synthesis after cuprizone-induced demyelination. J Neurosci 34(24):8186-8196. https://doi.org/10.1523/jneur osci.4267-13.2014

51. Sun W, McConnell E, Pare JF, Xu Q, Chen M, Peng W, Lovatt D, Han X, Smith Y, Nedergaard M (2013) Glutamate-dependent neuroglial calcium signaling differs between young and adult brain. Science 339(6116):197-200. https://doi.org/10.1126/scien ce. 1226740

52. Bruno V, Battaglia G, Casabona G, Copani A, Caciagli F, Nicoletti F (1998) Neuroprotection by glial metabotropic glutamate receptors is mediated by transforming growth factor-beta. J Neurosci 18(23):9594-9600

53. Caraci F, Molinaro G, Battaglia G, Giuffrida ML, Riozzi B, Traficante A, Bruno V, Cannella M, Merlo S, Wang X, Heinz BA, Nisenbaum ES, Britton TC, Drago F, Sortino MA, Copani A, Nicoletti F (2011) Targeting group II metabotropic glutamate (mGlu) receptors for the treatment of psychosis associated with Alzheimer's disease: selective activation of mGlu2 receptors amplifies beta-amyloid toxicity in cultured neurons, whereas dual activation of mGlu2 and mGlu3 receptors is neuroprotective. Mol Pharmacol 79(3):618-626. https://doi.org/10.1124/ mol.110.067488

54. Battaglia G, Riozzi B, Bucci D, Di Menna L, Molinaro G, Pallottino S, Nicoletti F, Bruno V (2015) Activation of mGlu3 metabotropic glutamate receptors enhances GDNF and GLT-1 formation in the spinal cord and rescues motor neurons in the SOD-1 mouse model of amyotrophic lateral sclerosis. Neurobiol Dis 74:126-136. https://doi.org/10.1016/j.nbd.2014.11.012

55. Durand D, Carniglia L, Turati J, Ramirez D, Saba J, Caruso C, Lasaga M (2017) Amyloid-beta neurotoxicity and clearance are both regulated by glial group II metabotropic glutamate receptors. Neuropharmacology 123:274-286. https://doi. org/10.1016/j.neuropharm.2017.05.008

56. Sofroniew MV (2014) Multiple roles for astrocytes as effectors of cytokines and inflammatory mediators. Neuroscientist 20(2):160-172. https://doi.org/10.1177/1073858413504466

57. Sofroniew MV (2005) Reactive astrocytes in neural repair and protection. Neuroscientist 11(5):400-407. https://doi. org/10.1177/1073858405278321

58. Anderson MA, Ao Y, Sofroniew MV (2014) Heterogeneity of reactive astrocytes. Neurosci Lett 565:23-29. https://doi. org/10.1016/j.neulet.2013.12.030

59. Pin JP, Duvoisin R (1995) The metabotropic glutamate receptors: structure and functions. Neuropharmacology 34(1):1-26

60. Dingledine R, Borges K, Bowie D, Traynelis SF (1999) The glutamate receptor ion channels. Pharmacol Rev 51(1):7-61

61. Karim F, Wang CC, Gereau RWt (2001) Metabotropic glutamate receptor subtypes 1 and 5 are activators of extracellular signal-regulated kinase signaling required for inflammatory pain in mice. J Neurosci 21(11):3771-3779
62. Hou L, Klann E (2004) Activation of the phosphoinositide 3-kinase-Akt-mammalian target of rapamycin signaling pathway is required for metabotropic glutamate receptor-dependent long-term depression. J Neurosci 24(28):6352-6361. https://doi. org/10.1523/jneurosci.0995-04.2004

63. Warwick HK, Nahorski SR, Challiss RA (2005) Group I metabotropic glutamate receptors, mGlu1a and mGlu5a, couple to cyclic AMP response element binding protein (CREB) through a common $\mathrm{Ca} 2+-$ and protein kinase $\mathrm{C}$-dependent pathway. J Neurochem 93(1):232-245. https://doi.org/10.111 1/j.1471-4159.2005.03012.x

64. Page G, Khidir FA, Pain S, Barrier L, Fauconneau B, Guillard O, Piriou A, Hugon J (2006) Group I metabotropic glutamate receptors activate the p70S6 kinase via both mammalian target of rapamycin (mTOR) and extracellular signal-regulated kinase (ERK 1/2) signaling pathways in rat striatal and hippocampal synaptoneurosomes. Neurochem Int 49(4):413-421. https://doi. org/10.1016/j.neuint.2006.01.020

65. Li XM, Li CC, Yu SS, Chen JT, Sabapathy K, Ruan DY (2007) JNK1 contributes to metabotropic glutamate receptor-dependent long-term depression and short-term synaptic plasticity in the mice area hippocampal CA1. Eur J Neurosci 25(2):391-396. https://doi.org/10.1111/j.1460-9568.2006.05300.x

66. Saugstad JA, Ingram SL (2008) Group I metabotropic glutamate receptors (mGluR1 and mGluR5). In: Gereau RW, Swanson GT (eds) The glutamate receptors. Human Press, Totowa, pp 387-464

67. Iacovelli L, Bruno V, Salvatore L, Melchiorri D, Gradini R, Caricasole A, Barletta E, De Blasi A, Nicoletti F (2002) Native group-III metabotropic glutamate receptors are coupled to the mitogen-activated protein kinase/phosphatidylinositol-3-kinase pathways. J Neurochem 82(2):216-223

68. Niswender CM, Conn PJ (2010) Metabotropic glutamate receptors: physiology, pharmacology, and disease. Annu Rev Pharmacol Toxicol 50:295-322. https://doi.org/10.1146/annurev.pharm tox.011008.145533

69. Geurts JJ, Wolswijk G, Bo L, van der Valk P, Polman CH, Troost D, Aronica E (2003) Altered expression patterns of group I and II metabotropic glutamate receptors in multiple sclerosis. Brain 126(Pt 8):1755-1766. https://doi.org/10.1093/brain/awg179

70. Geurts JJ, Wolswijk G, Bo L, Redeker S, Ramkema M, Troost D, Aronica E (2005) Expression patterns of Group III metabotropic glutamate receptors mGluR4 and mGluR8 in multiple sclerosis lesions. J Neuroimmunol 158(1-2):182-190. https:// doi.org/10.1016/j.jneuroim.2004.08.012

71. Newcombe J, Uddin A, Dove R, Patel B, Turski L, Nishizawa Y, Smith T (2008) Glutamate receptor expression in multiple sclerosis lesions. Brain Pathol 18(1):52-61. https://doi.org/10.1 111/j.1750-3639.2007.00101.x

72. Cai Z, Schools GP, Kimelberg HK (2000) Metabotropic glutamate receptors in acutely isolated hippocampal astrocytes: developmental changes of mGluR5 mRNA and functional expression. Glia 29(1):70-80

73. Pasti L, Volterra A, Pozzan T, Carmignoto G (1997) Intracellular calcium oscillations in astrocytes: a highly plastic, bidirectional form of communication between neurons and astrocytes in situ. J Neurosci 17(20):7817-7830

74. Shelton MK, McCarthy KD (1999) Mature hippocampal astrocytes exhibit functional metabotropic and ionotropic glutamate receptors in situ. Glia 26(1):1-11

75. Nett WJ, Oloff SH, McCarthy KD (2002) Hippocampal astrocytes in situ exhibit calcium oscillations that occur independent of neuronal activity. J Neurophysiol 87(1):528-537. https://doi. org/10.1152/jn.00268.2001 
76. Zur Nieden R, Deitmer JW (2006) The role of metabotropic glutamate receptors for the generation of calcium oscillations in rat hippocampal astrocytes in situ. Cerebral Cortex 16(5):676-687. https://doi.org/10.1093/cercor/bhj013

77. Copeland CS, Wall TM, Sims RE, Neale SA, Nisenbaum E, Parri HR, Salt TE (2017) Astrocytes modulate thalamic sensory processing via mGlu2 receptor activation. Neuropharmacology 121:100-110. https://doi.org/10.1016/j.neuropharm.2017.04.019

78. Cai Z, Kimelberg HK (1997) Glutamate receptor-mediated calcium responses in acutely isolated hippocampal astrocytes. Glia 21(4):380-389

79. Kimelberg HK, Cai Z, Schools G, Zhou M (2000) Acutely isolated astrocytes as models to probe astrocyte functions. Neurochem Int 36(4-5):359-367

80. Shrivastava AN, Kowalewski JM, Renner M, Bousset L, Koulakoff A, Melki R, Giaume C, Triller A (2013) beta-amyloid and ATP-induced diffusional trapping of astrocyte and neuronal metabotropic glutamate type-5 receptors. Glia 61(10):16731686. https://doi.org/10.1002/glia.22548

81. Vermeiren C, Hemptinne I, Vanhoutte N, Tilleux S, Maloteaux JM, Hermans E (2006) Loss of metabotropic glutamate receptor-mediated regulation of glutamate transport in chemically activated astrocytes in a rat model of amyotrophic lateral sclerosis. J Neurochem 96(3):719-731. https://doi.org/10.111 1/j.1471-4159.2005.03577.x

82. Aronica E, van Vliet EA, Mayboroda OA, Troost D, da Silva FH, Gorter JA (2000) Upregulation of metabotropic glutamate receptor subtype mGluR3 and mGluR5 in reactive astrocytes in a rat model of mesial temporal lobe epilepsy. Eur J Neurosci 12(7):2333-2344

83. Ferraguti F, Corti C, Valerio E, Mion S, Xuereb J (2001) Activated astrocytes in areas of kainate-induced neuronal injury upregulate the expression of the metabotropic glutamate receptors 2/3 and 5. Exp Brain Res 137(1):1-11. https://doi. org/10.1007/s002210000633

84. Ulas J, Satou T, Ivins KJ, Kesslak JP, Cotman CW, Balazs R (2000) Expression of metabotropic glutamate receptor 5 is increased in astrocytes after kainate-induced epileptic seizures. Glia 30(4):352-361

85. Umpierre AD, Bennett IV, Nebeker LD, Newell TG, Tian BB, Thomson KE, White HS, White JA, Wilcox KS (2016) Repeated low-dose kainate administration in C57BL/6J mice produces temporal lobe epilepsy pathology but infrequent spontaneous seizures. Exp Neurol 279:116-126. https://doi.org/10.1016/j. expneurol.2016.02.014

86. Nicholson KJ, Guarino BB, Winkelstein BA (2012) Transient nerve root compression load and duration differentially mediate behavioral sensitivity and associated spinal astrocyte activation and mGLuR5 expression. Neuroscience 209:187-195. https:// doi.org/10.1016/j.neuroscience.2012.02.027

87. Kim SK, Hayashi H, Ishikawa T, Shibata K, Shigetomi E, Shinozaki Y, Inada H, Roh SE, Kim SJ, Lee G, Bae H, Moorhouse AJ, Mikoshiba K, Fukazawa Y, Koizumi S, Nabekura J (2016) Cortical astrocytes rewire somatosensory cortical circuits for peripheral neuropathic pain. J Clin Investig 126(5):1983-1997. https://doi.org/10.1172/jci82859

88. Michot B, Deumens R, Hermans E (2017) Immunohistochemical comparison of astrocytic mGluR5 upregulation in infraorbital nerve- versus sciatic nerve-ligated rat. Neurosci Lett 653:113119. https://doi.org/10.1016/j.neulet.2017.05.035

89. Casley CS, Lakics V, Lee HG, Broad LM, Day TA, Cluett T, Smith MA, O'Neill MJ, Kingston AE (2009) Up-regulation of astrocyte metabotropic glutamate receptor 5 by amyloid-beta peptide. Brain Res 1260:65-75. https://doi.org/10.1016/j.brain res.2008.12.082
90. Lim D, Iyer A, Ronco V, Grolla AA, Canonico PL, Aronica E, Genazzani AA (2013) Amyloid beta deregulates astroglial mGluR5-mediated calcium signaling via calcineurin and Nf-kB. Glia 61(7):1134-1145. https://doi.org/10.1002/glia.22502

91. Aronica E, Catania MV, Geurts J, Yankaya B, Troost D (2001) Immunohistochemical localization of group I and II metabotropic glutamate receptors in control and amyotrophic lateral sclerosis human spinal cord: upregulation in reactive astrocytes. Neuroscience 105(2):509-520

92. Anneser JM, Chahli C, Ince PG, Borasio GD, Shaw PJ (2004) Glial proliferation and metabotropic glutamate receptor expression in amyotrophic lateral sclerosis. J Neuropathol Exp Neurol 63(8):831-840

93. Tang FR, Lee WL, Yeo TT (2001) Expression of the group I metabotropic glutamate receptor in the hippocampus of patients with mesial temporal lobe epilepsy. J Neurocytol 30(5):403-411

94. Aronica E, Yankaya B, Jansen GH, Leenstra S, van Veelen CW, Gorter JA, Troost D (2001) Ionotropic and metabotropic glutamate receptor protein expression in glioneuronal tumours from patients with intractable epilepsy. Neuropathol Appl Neurobiol 27(3):223-237

95. Aoki Y, Hanai S, Sukigara S, Otsuki T, Saito T, Nakagawa E, Kaido T, Kaneko Y, Takahashi A, Ikegaya N, Iwasaki M, Sugai K, Sasaki M, Goto Y, Oka A, Itoh M (2019) Altered expression of astrocyte-related receptors and channels correlates with epileptogenesis in hippocampal sclerosis. Pediatric Dev Pathol.https ://doi.org/10.1177/1093526619855488

96. Miller S, Romano C, Cotman CW (1995) Growth factor upregulation of a phosphoinositide-coupled metabotropic glutamate receptor in cortical astrocytes. J Neurosci 15(9):6103-6109

97. Nakahara K, Okada M, Nakanishi S (1997) The metabotropic glutamate receptor mGluR5 induces calcium oscillations in cultured astrocytes via protein kinase $\mathrm{C}$ phosphorylation. J Neurochem 69(4):1467-1475

98. Jean YY, Lercher LD, Dreyfus CF (2008) Glutamate elicits release of BDNF from basal forebrain astrocytes in a process dependent on metabotropic receptors and the PLC pathway. Neuron Glia Biol 4(1):35-42. https://doi.org/10.1017/s1740925x0 9000052

99. Yao HH, Ding JH, Zhou F, Wang F, Hu LF, Sun T, Hu G (2005) Enhancement of glutamate uptake mediates the neuroprotection exerted by activating group II or III metabotropic glutamate receptors on astrocytes. J Neurochem 92(4):948-961. https:// doi.org/10.1111/j.1471-4159.2004.02937.x

100. Umpierre AD, West PJ, White JA, Wilcox KS (2019) Conditional knock-out of mGluR5 from astrocytes during epilepsy development impairs high-frequency glutamate uptake. J Neurosci 39(4):727-742. https://doi.org/10.1523/jneurosci.1148-18.2018

101. Sulkowski G, Dabrowska-Bouta B, Kwiatkowska-Patzer B, Struzynska L (2009) Alterations in glutamate transport and group I metabotropic glutamate receptors in the rat brain during acute phase of experimental autoimmune encephalomyelitis. Folia Neuropathol 47(4):329-337

102. Sulkowski G, Dabrowska-Bouta B, Struzynska L (2013) Modulation of neurological deficits and expression of glutamate receptors during experimental autoimmune encephalomyelitis after treatment with selected antagonists of glutamate receptors. BioMed Res Int 2013:1-11. https://doi.org/10.1155/2013/186068

103. Fazio F, Notartomaso S, Aronica E, Storto M, Battaglia G, Vieira E, Gatti S, Bruno V, Biagioni F, Gradini R, Nicoletti F, Di Marco $R$ (2008) Switch in the expression of mGlu1 and mGlu5 metabotropic glutamate receptors in the cerebellum of mice developing experimental autoimmune encephalomyelitis and in autoptic cerebellar samples from patients with multiple sclerosis. Neuropharmacology 55(4):491-499. https://doi.org/10.1016/j.neuro pharm.2008.06.066 
104. Sulkowski G, Dabrowska-Bouta B, Salinska E, Struzynska L (2014) Modulation of glutamate transport and receptor binding by glutamate receptor antagonists in EAE rat brain. PLoS ONE 9(11):e113954. https://doi.org/10.1371/journal.pone.0113954

105. Dabrowska-Bouta B, Struzynska L, Chalimoniuk M, Frontczak-Baniewicz M, Sulkowski G (2015) The influence of glutamatergic receptor antagonists on biochemical and ultrastructural changes in myelin membranes of rats subjected to experimental autoimmune encephalomyelitis. Folia Neuropathol 53(4):317-326

106. Grolla AA, Sim JA, Lim D, Rodriguez JJ, Genazzani AA, Verkhratsky A (2013) Amyloid-beta and Alzheimer's disease type pathology differentially affects the calcium signalling toolkit in astrocytes from different brain regions. Cell Death Dis 4:e623. https://doi.org/10.1038/cddis.2013.145

107. Durand D, Carniglia L, Beauquis J, Caruso C, Saravia F, Lasaga M (2014) Astroglial mGlu3 receptors promote alpha-secretasemediated amyloid precursor protein cleavage. Neuropharmacology 79:180-189. https://doi.org/10.1016/j.neuropharm .2013.11.015

108. Rossi D, Brambilla L, Valori CF, Roncoroni C, Crugnola A, Yokota T, Bredesen DE, Volterra A (2008) Focal degeneration of astrocytes in amyotrophic lateral sclerosis. Cell Death Diff 15(11):1691-1700. https://doi.org/10.1038/cdd.2008.99

109. Vergouts M, Doyen PJ, Peeters M, Opsomer R, Hermans E (2018) Constitutive downregulation protein kinase $\mathrm{C}$ epsilon in hSOD1(G93A) astrocytes influences mGluR5 signaling and the regulation of glutamate uptake. Glia 66(4):749-761. https://doi. org/10.1002/glia.23279

110. Perry TL, Krieger C, Hansen S, Eisen A (1990) Amyotrophic lateral sclerosis: amino acid levels in plasma and cerebrospinal fluid. Ann Neurol 28(1):12-17. https://doi.org/10.1002/ ana.410280105

111. Rothstein JD, Van Kammen M, Levey AI, Martin LJ, Kuncl RW (1995) Selective loss of glial glutamate transporter GLT-1 in amyotrophic lateral sclerosis. Ann Neurol 38(1):73-84. https:// doi.org/10.1002/ana.410380114

Publisher's Note Springer Nature remains neutral with regard to jurisdictional claims in published maps and institutional affiliations. 